\title{
Scientists criticize DOE work on nuclear repository site
}

\begin{abstract}
Washington. A group of scientists who have reviewed plans for studying a proposed nuclear waste storage site in Nevada say that US government project managers have failed to follow the recommendations of a report issued last April by the National Academy of Sciences, with science taking a back seat to engineering and budgetary considerations. The scientists this week sent a letter expressing their concerns to the US Department of Energy (DOE), which manages the Yucca Mountain site survey.
\end{abstract}

The site has been controversial ever since it was chosen in 1987 as the prime candidate



DOE is taking an \$6-billion look at Yucca Mountain.

for a proposed underground repository for dumping nuclear waste from civilian US power plants. The mountain was selected for its geological stability and for the lack of rainfall in the region, which reduces the risk of radioactive contaminants leaching into groundwater. The site characterization studies, which will take another eight years, are expected to cost $\$ 6.3$ billion.

The National Academy of Sciences became involved in the controversy after a DOE staff hydrologist, Jerry Szymanski, claimed to have found evidence that groundwater under the mountain had risen high enough in the geological past to suggest that the repository might become flooded in the future. After two years of looking into the claim, the academy panel dismissed that worry - as have most independent scientists who have looked at Szymanski's evidence - but criticized other aspects of the project.

The panel report cited "a significant lack of communication among project scientists in different disciplines" and said that a chief scientist is needed. The report also recommended drilling deep into a palaeozoic aquifer under the area and taking core samples from a steep gradient lying just north of the site to characterize the regional hydrogeology better.

But DOE has chosen to "brush off" these and other suggestions, says George Thompson of Stanford University, vice chairman of the panel. In a 39-page letter sent in October to the academy, DOE said that exploring the gradient was worthwhile but probably would not be done for three to five years and that the deep drilling programme, if done at all, may include fewer holes than the panel recommended.

The response so displeased the panel members that they decided on the unusual step of a follow-up letter, even though the panel has been officially disbanded. All eight of the former panel members contacted about the letter agreed to sign, expressing frustration at what John Bredehoeft of the US Geological Survey (USGS) says is the DOE's attitude of "treating this thing as an engineering construction project instead of a broad-based scientific investigation".

Although DOE agrees with many of the panel's recommendations, says project manager Carl Gertz, its first step is building a huge ramp that will allow scientists access to the interior. While he is managing that engineering task, Gertz must also deal with pressure from Congress to go faster and spend less, with opposition from Nevada state officials and with public scepticism about the long-term safety of the repository. The government is required by 1998 to begin storing nuclear waste now piling up at power plants, so temporary sites will have to be used until a permanent repository is ready.

Gertz says that a chief scientist is not necessary because he already receives enough advice from researchers working on the project, including more than 200 from USGS. But investigators working at Yucca Mountain complain that most of the current budget is spent on engineers and administrators, who routinely ignore their advice and needs. The decision rests with the new DOE management team led by Energy Secretary Hazel O'Leary.

The members of the academy panel who signed the letter are not claiming that Yucca Mountain is unsuitable for storing nuclear waste. But they believe that the hydrogeology of the mountain must be better understood before DOE decides whether the repository is likely to remain safe and dry for at least 10,000 years.

Tony Reichhardt

\section{US judge throws out laboratory rules for dogs, primates}

Washington. A US federal judge has invalidated the system to regulate dogs and nonhuman primates used in research, in part relying on an ambiguous phrase in a 1985 law amending the Animal Welfare Act that has long bedevilled scientists. The government's dependence on veterinarians and institutional review committees has produced regulations that are "arbitrary and capricious", said the judge, who ordered the government to issue new regulations as quickly as possible. An appeal is considered likely.

District Court Judge Charles Richey ruled on 25 February that the US Department of Agriculture (USDA) and other federal agencies have failed to set minimum standards for the care and treatment of research animals, in particular criteria for exercising dogs and for ensuring the "psychological well-being" of primates. The latter is a phrase intended to improve conditions for research animals that was inserted by then Senator John Melcher into a 1985 amendment to the animal welfare laws. It has spawned considerable research, none of it conclusive, aimed at clarifying the conditions under which various species should be housed.

The suit was filed in May 1991 by animal rights groups after the government issued final regulations implementing the legislative changes. An earlier set of regulations was substantially revised after institutions complained about the cost of larger cages and more personal care.

"What Judge Richey has said is that USDA has to be the author of any regulation and that its delegation to the research industry of that power is illegal", says Valerie Stanley, the lawyer for the plaintiffs. "He also said that the rules must establish minimum standards, and that the industry's argument that there are too many exceptions doesn't hold water."

Last year, Richey ruled in favour of the same plaintiffs in a suit that challenged the USDA's exclusion of rats, mice and birds from the same law. In that case, against which the government has appealed, Richey said that there was no reason to omit the millions of rodents and birds used in research from its routine inspections and from guidelines for their proper care.

Research institutions believe that compliance will force them to spend millions of dollars on care that has not been shown to be beneficial to the animals. "The rules were meant to be a little vague", says Richard Traystman of Johns Hopkins University Medical School, "because we don't know, for example, what psychological well-being is for a monkey. The judge wants some precise answers, but they don't exist.'

Jeffrey Mervis 